\title{
Relationship between rainfall and water table in a coastal aquifer: the case study of Castelporziano presidential estate
}

\section{Relazione tra pioggia e superficie piezometrica in un acquifero costiero: il caso studio della Tenuta Presidenziale di Castelporziano}

Francesca Banzato, Marino Domenico Barberio, Andrea Del Bon, Alessandro Lacchini, Valentina Marinelli, Lucia Mastrorillo, Stefania Passaretti, Chiara Sbarbati, Marco Petitta

\begin{abstract}
Riassunto: Sono state analizzate le variazioni stagionali e annuali dei livelli piezometrici degli ultimi venti anni, relative all'acquifero della Tenuta Presidenziale di Castelporziano, che si estende per $59 \mathrm{~km}^{2}$ in un tratto costiero della periferia di Roma. Dal confronto con i trend delle precipitazioni locali, riferite alla stazione "Castello", a scala temporale mensile, stagionale e pluriennale, sono state evidenziate delle differenze tra i diversi settori della Tenuta. Nella parte costiera l'effetto della ricarica meteorica sul regime di variabilità della falda è diretto e regolare nel corso dell'anno. Invece, negli altri settori è stato evidenziato un regime annuale stazionario e dei trend pluriennali, che suggeriscono un contributo dall'adiacente acquifero vulcanico dei Colli Albani, fortemente influenzato da intensi prelievi. La prosecuzione dei monitoraggi permetterà di definire con maggiore chiarezza la circolazione idrica sotterranea dell'acquifero costiero di Castelporziano.
\end{abstract}

Keywords: coastal aquifer, protected area, water table monitoring, rainfall.

Parole chiave: acquifero costiero, area protetta, monitoraggio dei livelli piezometrici, piogge.

Francesca BANZATO 奉”

Marino Domenico BARBERIO, Andrea DEL BON

Alessandro LACCHINI, Valentina MARINELLI

Stefania PASSARETTI, Chiara SBARBATI, Marco PETITTA

Earth Science Department, Sapienza University of Rome

Piazzale Aldo Moro 5, 00185 Rome, Italy

francesca.banzato@uniroma1.it

Lucia MASTRORILLO

Sciences Department, Roma Tre University, Italy

Ricevuto/Received:14 February 2019-Accettato/Accepted: 16 March 2019 Pubblicato online/Published online: 29 March 2019

This is an open access article under the CC BY-NC-ND license: http://creativecommons.org/licenses/by-nc-nd/4.0/

CC Associazione Acque Sotterranee 2019
Abstract: This study is focused on the analysis of seasonal and annual variability of water table during last 20 years of the coastal aquifer of Castelporziano Presidential Estate, a protected area of $59 \mathrm{Km}^{2} \mathrm{lo}_{-}$ cated in the periphery of Rome. A comparison with the local trends of rainfall at "Castello" gauging station at different time scales (monthly, seasonal and annual) has been carried out. The results highlight differences between the coastal area and eastern and northern sector of the Estate. Indeed, the seasonal effect due to local meteoric recharge is direct and regular during the year in the coastal area in respect to the eastern and northern sectors of the Estate. Moreover, annual steady regime and multi-year trend of groundwater levels suggest the contribution from the adjacent volcanic aquifer of Albani Hills. In the latter case, the regional groundwater flow is affected by the intense withdrawals. The maintenance of the monitoring network will allow to define the flow paths of the groundwater that characterize the coastal aquifer of Castelporziano.

\section{Introduction}

The Castelporziano Presidential Estate is located about $25 \mathrm{~km} \mathrm{SW}$ from the city center of Rome and extends over a surface of $59 \mathrm{~km}^{2}$. This protected site includes coastal ecosystems typical of the Mediterranean area with a great variety of vegetation and of wildlife species. The environmental relevance of Castelporziano Estate is ensured by the protection measures aimed at safeguarding the naturalistic value, including groundwater resources, in one of the few protected areas in the city of Rome. The environmental monitoring system of the study area was established 20 years ago and provides rainfall data, groundwater level data of the coastal aquifer and chemical-physical parameters about the quality of groundwaters.

As mentioned before, the collected data are related to a protected area where the groundwater variations depend exclusively on seasonal variability of meteoric recharge. For this reason this study is focused on the analysis of seasonal and annual variability in groundwater levels of the Castelporziano coastal aquifer and the comparison with the local trends of rainfall at different time scales (monthly, seasonal and annual). 


\section{Study Area}

The geological-stratigraphic and geomorphological evolution of the Castelporziano Estate area is influenced by the Tiber river, whose delta is located very close to the study area. Four main morphological structures, arranged in an almost parallel sequence with NW-SE direction, extend from the coastline to the northern boundary of the Presidential Estate. Proceeding from the sea to the hinterland it's possible to find (Bucci and Grillini 2001; Mastrorillo and Petitta 2010; Mastrorillo et al. 2016a):

- the coastal plain, which extends from the coastline to an altitude of about 20 meters a.s.l.;

- two order of marine terraces, between 20 and 40 meters a.s.l.;

- a plateau, which develops over 40 meters a.s.1.;

- the plateau top, located at an altitude of around 80 meters a.s.l., that coincides with the hydrographic watershed between the drainage directed towards the sea and that of the Malafede Trech catchment area.
The deposits that outcrop in the study area are related to sands of coastal or deltaic origin (Fig. 1), having significant heterogeneity, due to the evolution of the delta of the Tiber river in the Holocene times (Milli et al. 2013; Bellotti et al. 2007; Bucci M. and Grillini M. 2001). The inland sector of the delta plain is characterized by Pleistocene transitional mid-littoral deposits, consisting mainly of sands, such as that of "ancient Red Dune" (Mastrorillo et al. 2018; Funiciello and Giordano 2008; Bucci and Grillini 2001). In the seaside sector, up to an altitude of about 5 meters a.s.l., only the recent Holocene deposits are present.

In the areas of the terraces and plateau, under the sandy cover, volcanic products of the Albani Hills and heterogeneous deposits including gravels, sands, silts of continental, coastal and marine origin, refer to the "Ponte Galeria Formation" have been found (Bucci and Grillini 2001). The deepest boreholes drilled in the area passed the sands and reached a clay bedrock at an approximate depth of 25 meter a.s.l.; towards the sea, the bedrock deepening until -40 meter a.s.1. (Bucci and Grillini 2001; Mastrorillo and Mazza 2015).

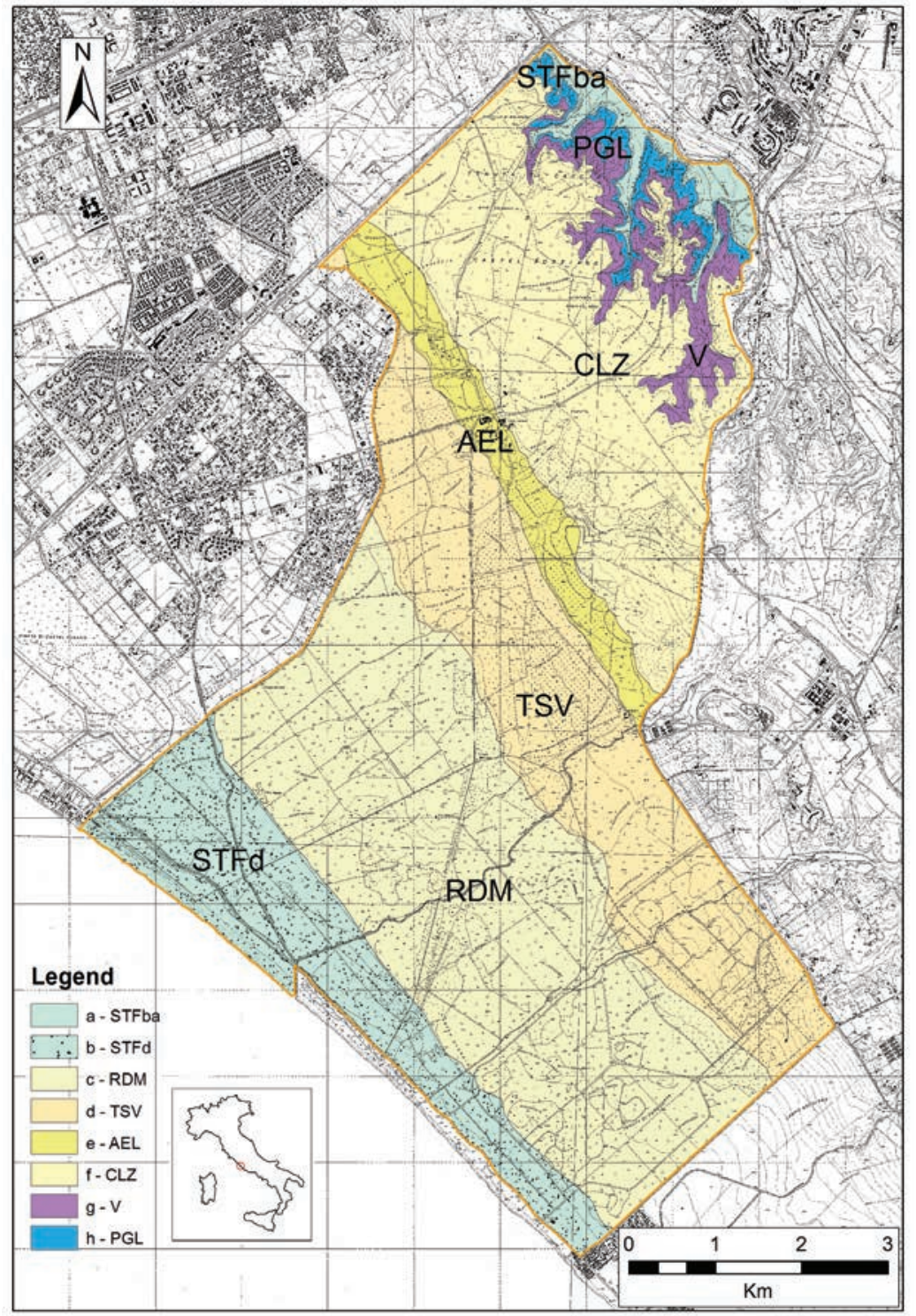

Fig. 1 - Deposits outcropping in the study area of Castelporziano Presidential Estate. Holocene deposits of alluvial (a) or coastal (b) origin; Pleistocene sands (c-f), terraced between 20 and 40 meters a.s.l.; volcanic products of the Albani Hills (g); continental deposits (b). For the abbreviations shown in the geological sketch refer to Geological Map of Italy, 1:50.000 - sheet 374 "Roma" (Funiciello and Giordano 2008).

Fig. 1 - Depositi affioranti nell'area di studio della Tenuta Presidenziale di Castelporziano. Depositi Olocenici di origine alluvionale (a) o costiera (b); sabbie Pleistoceniche (c-f), terrazzate tra 20 e 40 metri s.l.m.; prodotti vulcanici dei Colli Albani (g); depositi continentali (h). Per le sigle riportate nello schema geologico riferirsi al Foglio 374 "Roma" della Carta Geologica d'Italia alla scala 1:50.000 (Funiciello e Giordano 2008). 
The Pleistocene clay bedrock, characterized by a low permeability, acts as aquiclude for the groundwater flow in the coastal aquifer of Castelporziano area.

The monitored aquifer corresponds to the hydrogeological complex of heterogeneous Holocene - Pleistocene deposits, made mostly of sandy sediments. The groundwater recharge is ensured by the presence of permeable sands with a higher net infiltration and the hydraulic connection of the groundwater is guaranteed by the spatial continuity of the gravel horizons interbedded with the sand and silty layers (La Vigna et al. 2016; Mastrorillo et al. 2016b; Mastrorillo and Mazza 2015).

Drainage occurs mainly towards the sea, parallel to the coast from NE to SW, and towards the delta of Tiber river, located to the West respect to Castelporziano area. The groundwater table is characterized by a hydraulic gradient of about $1 \%$ that decreases until $0.3 \%$ in correspondence of the Holocene deposits.

The hydrogeological framework of the coastal aquifer of Castelporziano is strongly influenced by two characteristics: the clay basement morphology and the "Malafede ditch", which borders the north-east side of the study area. In fact, the clay bedrock, corresponding to the top of the basal aquiclude (TSBA) in the Rome district (Dimasi et al. 2015), in the study area rises up to 25 meters a.s.l., with NW-SE direction. This hydrogeological horst according to Authors (La Vigna et al. 2015; Mastrorillo and Mazza 2015; Mastrorillo and Petitta 2010; Bucci and Grillini 2001) marked the northeastern limit of the hydrogeological basin of Castelporziano, separating the groundwater flow of the Estate, that flow towards the Thyrrenian sea, from the external one of Alban Hills. According to this hydrogeological framework, the Castelporziano aquifer is hydraulically isolated from the adjacent volcanic aquifer due to the presence of the "Malafede ditch", that partially drains the hydrogeological basin of the Alban Hills Unit (Capelli and Mazza 2005; Capelli et al. 2005). Consequently, the groundwater flow seems to be ensured exclusively by local meteoric input.

Otherwise, in the northern sector of the Castelporziano aquifer a contribution from the volcanic aquifer outcropping East of the study area has been verified (Banzato et al. 2013): the groundwater flows from East, where the higher groundwater levels have been measured, to West.

\section{Collected data}

Groundwater table of Castelporziano aquifer is monitored by a network of 35 piezometers, homogeneously distributed in the area of the Estate (Fig. 2). Monitoring wells are from 10 to over 60 meters deep and the shallowest ones are located in the seaside sector. Data were manually collected monthly and quarterly since 1997. From 2005, 14 monitoring wells have been equipped with automatic probes for daily measurement of groundwater levels.

The monitoring of climatic data in the study area is performed thanks to the presence of 3 weather stations, equipped by the "Osservatorio Multidisciplinare" of the Presidential Estate. This gauging stations are located in the Castelporziano area, at a similar altitude but have been activated in different times. TThe "Castello" gauging station is located in the middle of the study area $(60 \mathrm{~m}$ a.s.l) and has THE longest and most continuous data set available. For this reason, continuous daily rainfall data from February 1981 to November 2018 of this station could be considered representative of the seasonal and annual rainfall trends in the whole area of the Estate.

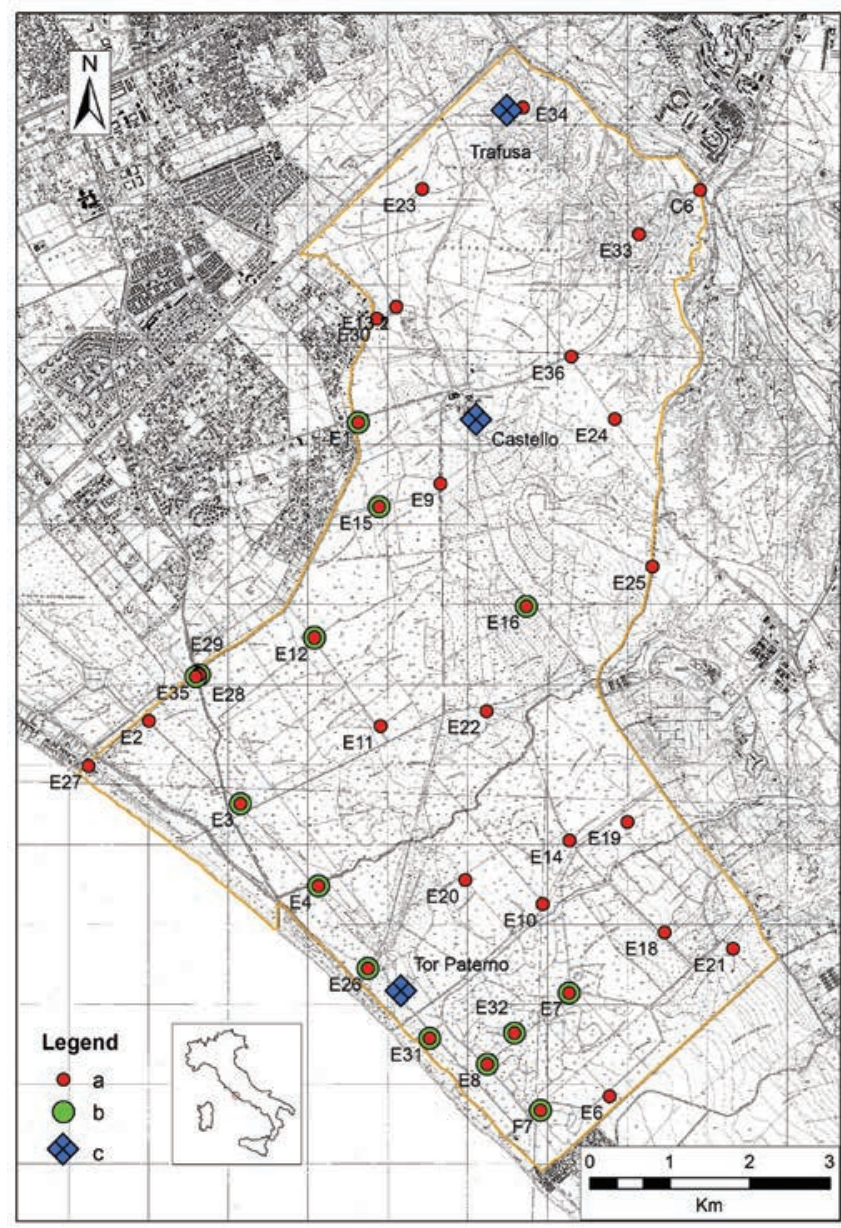

Fig. 2 - Sketch map of monitoring points in the Castelporziano Estate. a) piezometers; b) piezometers with automatic probe; c) rain gauge stations.

Fig. 2 - Schema dei punti di monitoraggio nella Tenuta di Castelporziano. a) piezometri; b) piezometri con sonde automatiche; c) stazioni pluviometriche.

\section{Results and discussion}

The analysis of pluviometric trends related to Castello station confirmed a maritime type regime with dry summers and rainy autumn-winters (Fig. 3a). The rainfall events are mainly concentrated in autumn season and the highest mean values are referred to October and November (about $110 \mathrm{~mm} /$ month). During the winter rainfall varies from 60 to $90 \mathrm{~mm} /$ month, while from April the mean monthly values gradually decrease until July, when the lowest value $(16 \mathrm{~mm})$ is reached. The dry season, with monthly average values lower than 20 $\mathrm{mm}$, is however characterized by short but intense rainfall events. 

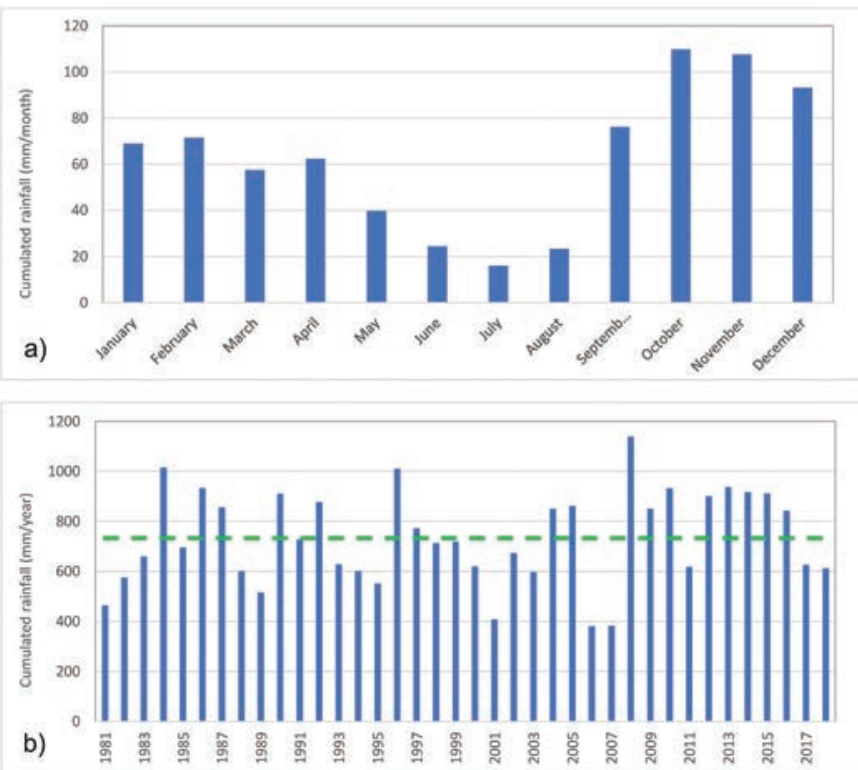

Fig. 3 - Pluviometric trend analysis related to Castello station. a) Mean monthly rainfall, referred to 1981-2018 period; b) annual cumulated rainfall. The green dashed line refers to the annual average rainfall value in 1981-2018 period.

Fig. 3 - Analisi dei trend pluviometrici relative alla stazione Castello. a) Valore medio mensile relativo al periodo 1981-2018. b) Pioggia cumulata annuale. La linea verde tratteggiata indica il valore medio per il periodo 1981-2018.

In detail, referring to annual cumulated rainfall for 19812018 monitoring period, the long-term values range between a minimum of $400 \mathrm{~mm}$, recorded in the 2001, 2006-2007 dry years, and over $1000 \mathrm{~mm}$ in the wettest years, like 1984, 1996 and 2008 (Fig. 3b). The average value is about $730 \mathrm{~mm} /$ year. On a multi-annual scale, the pluviometric regime recorded during the study period is characterized by fluctuations with a frequency of about $4-5$ years, as documented at a regional scale for the Central Apennine District (Romano et al. 2017).

The persistence of drought periods during the hydrological year can have consequences on local or regional groundwater flows. This is clearly shown in the multi-year trend of groundwater levels recorded in the northern and eastern sectors of Castelporziano Estate area. In E19-E21 piezometers (Fig. 4a) and in E24-E25 piezometers (Fig. 4b) exhaustion periods extended for several years can be observed. The delay between the wettest years (Fig. 4c) and the rise of water table levels have been estimated in at least two years. Similarly, the surveys conducted in 2018 have shown a decrease of piezometric levels due to the delayed effect of the rainfall deficit which characterized 2017 (Romano et al. 2017).

Moreover, a general annual variation of tens centimeters occurs, testifying a steady regime of water table in the north-eastern sector of Castelporziano aquifer. This evidence suggests a potential contribution from the adjacent volcanic aquifer of Alban Hills, because the regional groundwater flow is less affected by the recharge due to local precipitation. However, in the protected area of Castelporziano, a significant decrease of piezometric levels since late 90's to 2004-2005 has been recognized: this can be interpreted as an evidence of the contribution in the north-eastern area of Castelporziano
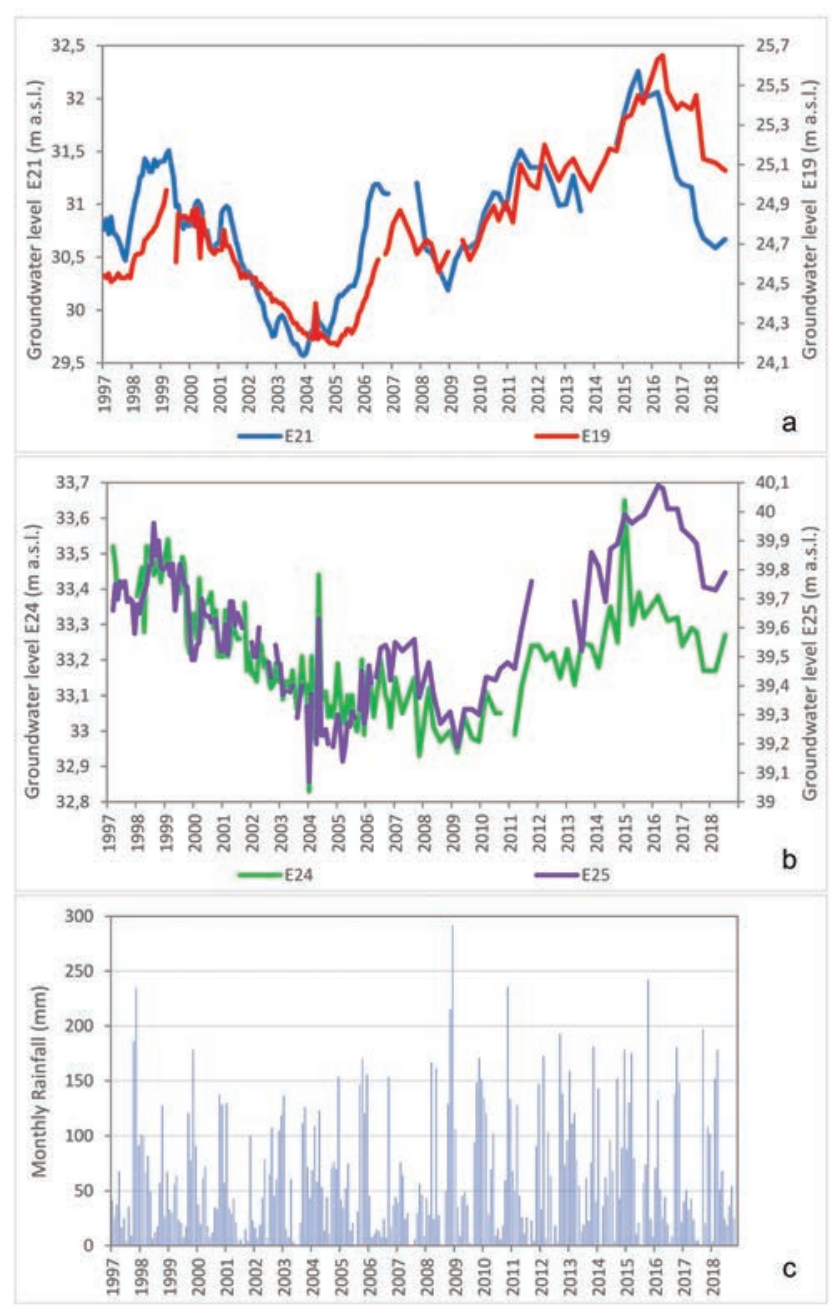

Fig. 4 - Water table monitoring (1997-2018) for representative piezometers in the eastern (a) and northern (b) sectors of the Castelporziano Estate and relative monthly rainfalls (c).

Fig. 4 - Monitoraggio della falda (1997-2018) in piezometri rappresentativi dei settori orientale (a) e settentrionale (b) della Tenuta di Castelporziano e relative piogge mensili (c).

aquifer from the adjacent volcanic one. In fact, since 1990s, a significant drawdown of the water table, has been already documented (Capelli and Mazza 2005), due to over-exploitation of the Colli Albani Hydrogeological basin. In this perspective, the rise of the water table in the last decade (Fig. 4) could be attributed to two factors: the implementation of new policies about groundwater safeguarding by the local authorities (Bianchini 2013; Regione Lazio 2004) and a meteoric recharge above the average value between 2008-2016.

Figure 5 shows water table changes compared with monthly rainfall for two piezometers located in the western sector of the study area. Here, seasonal variations of the water table are identified: these are delayed of 1-2 months respect with rainfall, evidencing the role of the unsaturated zone on aquifer recharge that in this sector reaches a thickness of about 50 meters.

Conversely, in the coastal area the oscillation of the water table follows a seasonal trend directly due to the rainfall 
events. During the fall-winter seasons there is a progressive rise of piezometric levels that reaches the highest values in February-March, followed by an exhaustion period showing the lowest values at the end of the summer (Fig. 6).

The steady regime of groundwater table in the Castelporziano area is confirmed by the piezometric maps referred to the highest (Fig. 7a) and the lowest (Fig. 7b) water table levels recorded in the study area. Variation of the water table levels occurs mainly in the north-western sector, leading the groundwater flow towards the delta of Tiber river.

\section{Conclusions}

The coastal aquifer of the Castelporziano Presidential Estate represents a peculiar hydrogeological system due to the restriction of human activities. The results of monitoring related to the water table and the rainfall trends during last

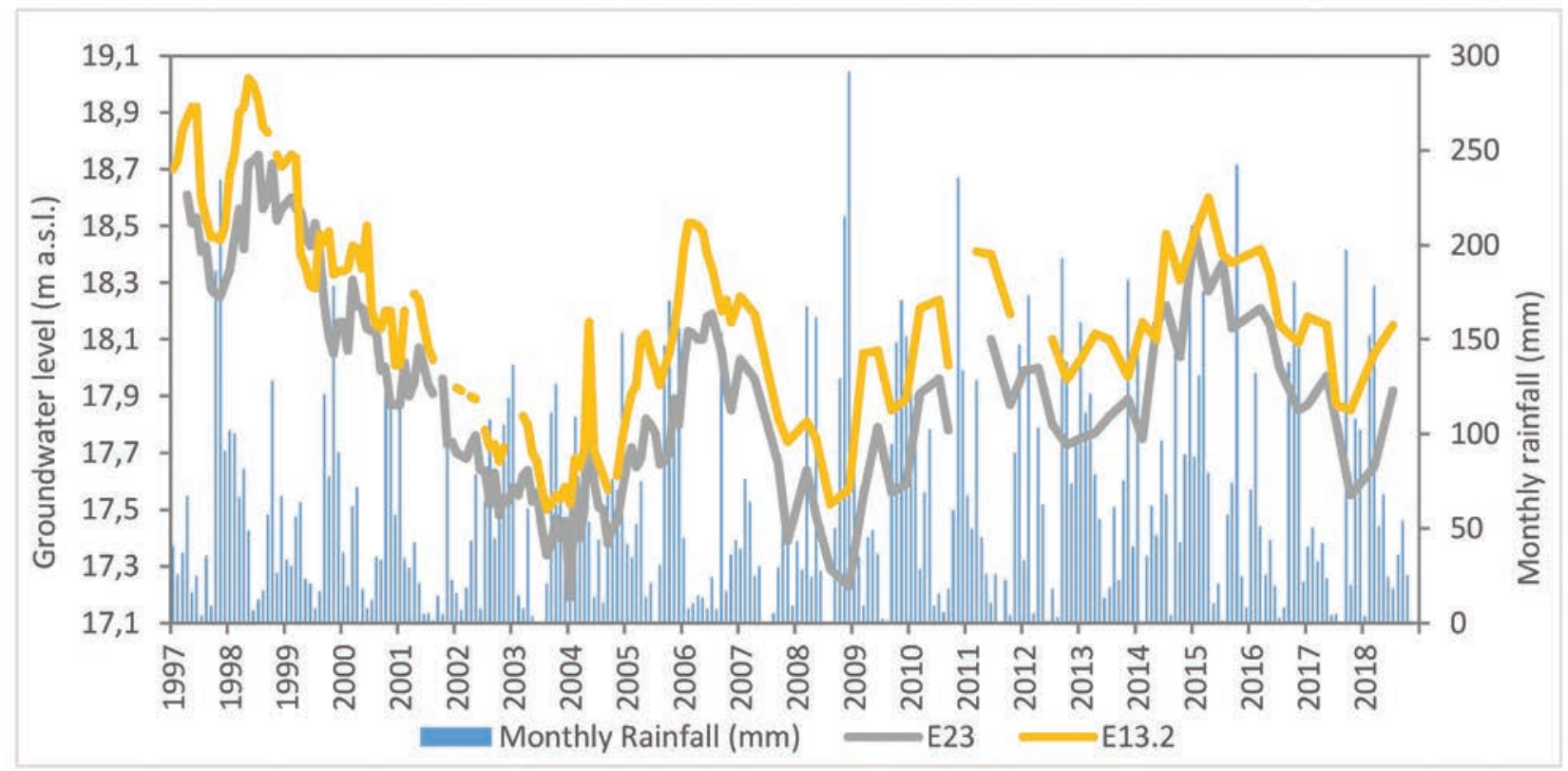

Fig. 5 - Comparison between monthly cumulated rainfall and water table in the western sector of Castelporziano Estate.

Fig. 5 - Confronto tra piogge cumulate mensili e livelli della falda nel settore occidentale della Tenuta di Castelporziano.

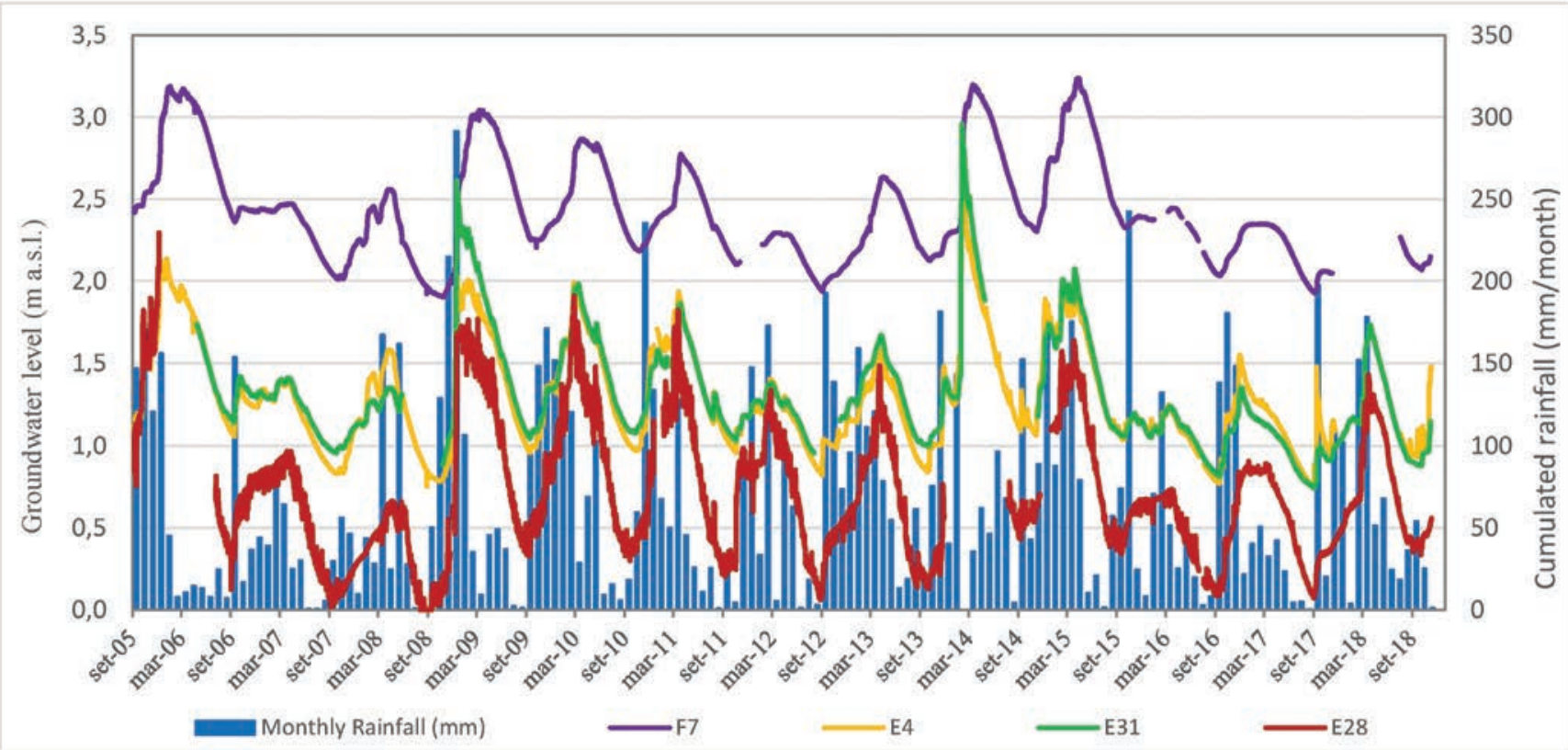

Fig. 6 - Variations of piezometric levels measured by automatic probes in representative wells of the coastal area.

Fig. 6 - Variazioni dei livelli piezometrici misurate dale sonde automatiche in pozzi rappresentativi del settore costiero. 


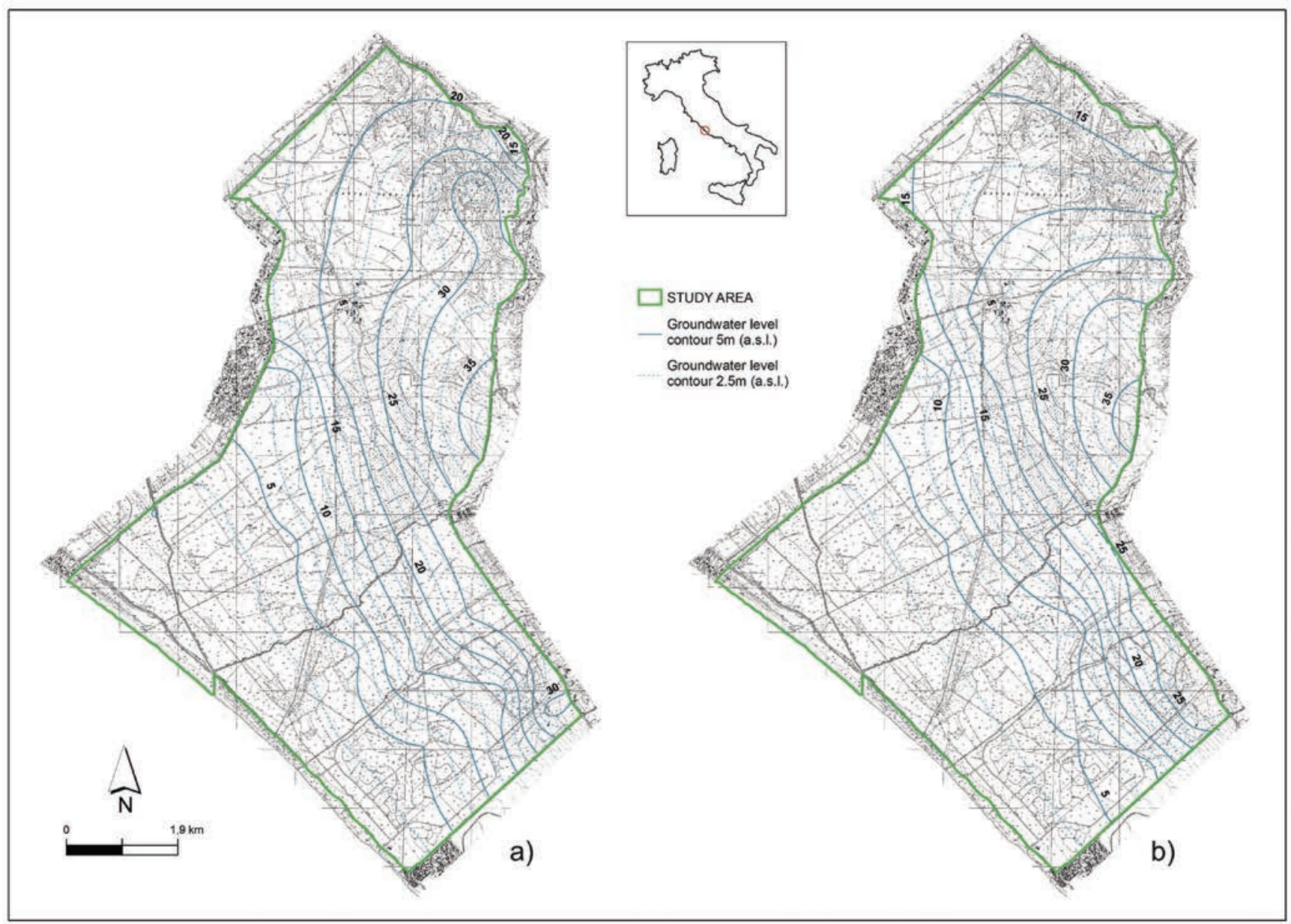

Fig. 7 - Piezometric maps of the study area, related to maximum a) and minimum b) groundwater levels.

Fig. 7 - Mappe piezometriche dell'area di studio, relative al massimo a) e al minimo b) stazionamento dei livelli di falda.

20 years, highlight differences between the coastal area, where the seasonal effect due to local meteoric recharge is direct, respect with the eastern and northern sectors of the Estate. Steady annual water table values and multi-year trend of groundwater levels confirm a potential contribution from the adjacent volcanic aquifer of Albani Hills, whose regional groundwater flow strongly suffered the effects of intense withdrawals rather than a decrease in meteoric recharge. The intense monitoring results to be very useful to define the groundwater flowpaths that characterize the Castelporziano coastal aquifer.

Acknowledgment: the Authors are thankful to the "Osservatorio Multidiscliplinare per lo Studio degli Ecosistemi Costieri Mediterranei" of the Castelporziano Presidential Estate for the provided data and for access permission to the monitoring activities. The monitoring activity is continuously supported by grant of the "Accademia Nazionale delle Scienze detta dei XL".

\section{REFERENCES}

Banzato F, Caschetto M, Lacchini A, Marinelli V, Mastrorillo L, Sbarbati C (2013) Recharge and groundwater flow of the coastal aquifer of castelporziano Presidential Estate (Rome, Italy). Rend. Online Soc. Geol. It., Vol. 24: 22-24.

Bellotti P, Calderoni G, Carboni MG, Di Bella L, Tortora P, Valeri P, Zernitskaya V (2007) Late Quaternary landscape evolution of the Tiber River delta plain (central Italy): new evidence from pollen data, biostratigraphy and C-14 dating. Zeitschrift fur Geomorphologie, 51(4): 505-534.

Bianchini A (2013) L'iter normativo della definizione delle aree critiche e d'attenzione nel Lazio "The legislative procedure for the definition of critical and of attention areas in the Lazio region". Acque Sotterranee - Italian Journal of Groundwater, 2(4). https://doi. org/10.7343/as-055-13-0082

Bucci M, Grillini M (2001) Studi geologici, geomorfologici ed idrogeologici nella Tenuta Presidenziale di Castelporziano. Il sistema ambientale della Tenuta Presidenziale di Castelporziano "Geological, geomorphological and hydrogeological studies in the Presidential Estate of Castelporziano. The environmental system of the Presidential Estate of Castelporziano", Scritti e Documenti XXVI Accademia Nazionale delle Scienze (I):123-155.

Capelli G, Mazza R (2005) Water criticality in the Colli Albani (Rome, Italy). doi: 10.1474/GGA.2005-01.0-26-0026. 
Capelli G, Mazza R, Gazzetti C (Eds.) (2005) Strumenti e strategie per la tutela e l'uso compatibile della risorsa idrica nel Lazio "Tools and strategies for protection and sustenable using of the water resource in the Lazio Region". Gli acquiferi vulcanici (Vol. 78). Pitagora.

Dimasi M, Mancini M, Mazza R (2015) Superficie di tetto dell'Aquiclude basale "Top surface of the basal Aquiclude". In: La Vigna F and Mazza R (Eds) Carta idrogeologica di Roma. Scala 1:50.000 - Hydrogeological Map of Rome. Scale 1:50.000.

Funiciello R, Giordano G (Eds.) (2008) Roma: foglio 374 "Geological map of Italy 1:50.000, Sheet 374 "Roma". Università degli studi Roma Tre. Dipartimento di scienze geologiche.

La Vigna F, Mazza R, Amanti M, Di Salvo C, Petitta M, Pizzino L, Pietrosante A, Martarelli A, Bonfà I, Capelli G, Cinti D, Ciotoli F, Ciotoli G, Conte G, Del Bon A, Dimasi M, Falcetti S, Gafà R M, Lacchini A, Mancini M, Martelli S, Mastrorillo L, Monti G M, Procesi M, Roma M, Sciarra A, Silvi A, Stigliano F, Succhiarelli C (2016) Groundwater of Rome, Journal of Maps, 12:sup1, 88-93, DOI: $10.1080 / 17445647.2016 .1158669$

La Vigna F, Mazza R, Pietrosante A, Martarelli L, Di Salvo C (2015) Unità idrogeologiche del territorio romano e modello concettuale di circolazione. "Hydrogeological Units of roman area and groundwater conceptual model". In: La Vigna F and Mazza R (Eds) Carta idrogeologica di Roma. Scala 1:50.000 - Hydrogeological Map of Rome. Scale 1:50.000.

Mastrorillo L, Mazza R, Viaroli S (2018) Recharge process of a dune aquifer (Roman coast, Italy). Acque Sotterranee - Italian Journal of Groundwater, 7(4). https://doi.org/10.7343/as-2018-356

Mastrorillo L, Mazza R, Manca F, Tuccimei P (2016a) Evidences of different salinization sources in the roman coastal aquifer (Central Italy). J Coast Conserv 20:423-441. doi:10.1007/s11852-016-0457-5
Mastrorillo L, Mazza R, Tuccimei P, Rosa C, Matteucci R (2016b) Groundwater monitoring in the archaeological site of Ostia Antica (Rome, Italy): first results. Acque Sotterranee - Italian Journal of Groundwater, 5(1). https://doi.org/10.7343/as-2016-192

Mastrorillo L, Mazza R (2015) L'acquifero costiero del litorale romano "The roman coastal aquifer". In: La Vigna F and Mazza R (Eds) Carta idrogeologica di Roma. Scala 1:50.000 - Hydrogeological Map of Rome. Scale 1:50.000.

Mastrorillo L, Petitta M (2010) La rete di monitoraggio idrogeologico della Tenuta Presidenziale di Castelporziano (Roma). IX Giornata Mondiale dell'Acqua. Il bacino del Tevere "The groundwater monitoring network of Castelporziano Presidential Estate (Rome). IX World Water day. The Tiber river basin". Atti dei convegni Lincei, 254:105-118.

Milli S, D’Ambrogi C, Bellotti P, Calderoni G, Carboni MG, Celant A, Di Bella L, Di Rita F, Frezz V, Magri D, Pichezzi RM, Ricci V (2013) The transition from wave-dominated estuary to wave-dominated delta: the Late Quaternary stratigraphic architecture of Tiber River deltaic succession (Italy). Sedimentary Geology 284:159-180.

Regione Lazio (2004) Misure di salvaguardia degli acquiferi vulcanici dei Colli Albani e dei Monti Sabatini "Safeguard measures of the Albani Hills and the Sabatini Mounts volcanic aquifers". Bollettino Ufficiale della Regione Lazio suppl. Ordinario n.4 del "Bollettino Ufficiale" n. 2 del 20 gennaio 2004 .

Romano E, Guyennon N, Petrangeli AB, Preziosi E (2017) Caratterizzazione climatica del regime pluviometrico nell'area del Distretto Idrografico dell'Appennino centrale nel periodo 1951-2017. Osservatorio utilizzi idrici Distretto Idrografico dell'Appennino centrale. "Climatic characterization of the pluviometric trend in the area of the Central Apennine Hydrographic District during the 1951-2017 period. Observatory of the water uses in the Central Apennine Hydrographic District". Available from: http://www.irsa.cnr.it/index.php/ita/news/item/192report-regime-climatico - last accessed 01/02/2019 